\title{
The Effect of Lignin Composition on Ruminal Fiber Fractions Degradation from Different Roughage Sources in Water Buffalo (Bubalus bubalis)
}

\author{
Huimin Zhong ${ }^{1}$, Jiayan Zhou ${ }^{1}$, Mohamed Abdelrahman ${ }^{1,2} \oplus$, Hao Xu ${ }^{1}$, Zian Wu ${ }^{1}$, Luncheng Cui ${ }^{1}$, \\ Zhenhua Ma ${ }^{1}$, Liguo Yang ${ }^{1,3}$ and Xiang $\mathrm{Li}^{1,3,4, *(\mathbb{D})}$
}

1 National Center for International Research on Animal Genetics, Breeding and Reproduction (NCIRAGBR), Huazhong Agricultural University, Wuhan 430070, China; HuiminZhong@webmail.hzau.edu.cn (H.Z.); JiayanZhou@webmail.hzau.edu.cn (J.Z.); mohamed.asaad@webmail.hzau.edu.cn (M.A.); hom@webmail.hzau.edu.cn (H.X.); wuzian@webmail.hzau.edu.cn (Z.W.); 2017302110087@webmail.hzau.edu.cn (L.C.); mzh72520@163.com (Z.M.); ylg@mail.hzau.edu.cn (L.Y.)

2 Animal Production Department, Faculty of Agriculture, Assuit University, Asyut 71515, Egypt

3 Key Laboratory of Agricultural Animal Genetics, Breeding and Reproduction of Ministry of Education, College of Animal Science and Technology, Huazhong Agricultural University, Wuhan 430070, China

4 Shennongjia Science \& Technology Innovation Center, Huazhong Agricultural University, Wuhan 430070, China

* Correspondence: xxianglli@mail.hzau.edu.cn; Tel.: +86-18995622055

check for updates

Citation: Zhong, H.; Zhou, J.; Abdelrahman, M.; Xu, H.; Wu, Z.; Cui, L.; Ma, Z.; Yang, L.; Li, X. The Effect of Lignin Composition on Ruminal Fiber Fractions Degradation from Different Roughage Sources in Water Buffalo (Bubalus bubalis). Agriculture 2021, 11, 1015. https: / / doi.org/10.3390/agriculture11101015

Academic Editor: Alena Pechová

Received: 14 August 2021

Accepted: 15 October 2021

Published: 17 October 2021

Publisher's Note: MDPI stays neutral with regard to jurisdictional claims in published maps and institutional affiliations.

Copyright: (c) 2021 by the authors. Licensee MDPI, Basel, Switzerland. This article is an open access article distributed under the terms and conditions of the Creative Commons Attribution (CC BY) license (https:// creativecommons.org/licenses/by/ $4.0 /)$.
Abstract: The water buffalo (Bubalus bubalis) is known for its unique utilization of low-quality fibrous feeds and outstanding digestion performance, highlighting its role as an animal model in studying fiber fractions degradation. Among roughage, lignin attracted wide attention in ruminant nutrition studies, which affects animal digestibility. Therefore, the present study aims to investigate the functional relation between three lignin monomeric compositions of coniferyl alcohol (G), $\rho$ coumaryl alcohol (H) and sinapyl alcohol (S) and ruminal fiber degradation in water buffalo. Hence, three female water buffaloes (Nili-Ravi $\times$ Mediterranean, five years old, $480 \pm 20 \mathrm{~kg}$ ) were assigned for an in vivo study by utilizing the nylon-bag method, examining eight kinds of roughage. All the experimental roughage types were analyzed for the effective degradability (ED) of neutral detergent fiber (NDF), acid detergent fiber (ADF), acid detergent lignin (ADL), cellulose (CEL) and hemicellulose (HC) fractions. Then, prediction models for the roughage fiber degradation were established based on the characteristics of lignin monomer content. The results showed that $\mathrm{S}$, $\mathrm{S} / \mathrm{G}$ and $\mathrm{S} /(\mathrm{G}+\mathrm{S}+\mathrm{H})$ were positively correlated with the ED of NDF, ADF, CEL and HC; H/S was negatively correlated. For the effective degradability of ADL (ADLD), $\mathrm{S}$ and $\mathrm{S} /(\mathrm{G}+\mathrm{S}+\mathrm{H})$ were positively correlated with it; $\mathrm{H}, \mathrm{H} / \mathrm{G}, \mathrm{H} / \mathrm{S}$ and $\mathrm{H} /(\mathrm{G}+\mathrm{S}+\mathrm{H})$ were negatively correlated. The model with the highest fitting degree was ADLD $=0.161-1.918 \times \mathrm{H}+3.152 \times \mathrm{S}\left(\mathrm{R}^{2}=0.758, p<0.01\right)$. These results indicated that the lignin monomer composition is closely related to the utilization rate of roughage fiber. S-type lignin monomer plays a vital role in the fiber degradation of roughage. The experiment found the effect of lignin monomer composition on the degradation of fiber fractions using buffalo as the experimental animal and constructed prediction models, providing a scientific basis for building a new technological method using lignin composition to evaluate buffalo roughage. Furthermore, the capacity of ADL degradation of buffalo was proved in this experiment. In order to further explore the ability of lignin degradation by the buffalo, the DNA of rumen microorganisms was extracted for sequencing. The top three composition of rumen microorganisms at the genus level were Prevotella_1, 226, Rikenellaceae_RC9_gut_group and Ruminococcaceae_UCG-011. Six strains with lignin degradation ability were screened from buffalo rumen contents. This experiment also revealed that the buffalos possess rumen microorganisms with lignin degradation potential.

Keywords: lignin monomer; roughage; degradation; buffalo; rumen microorganisms 


\section{Introduction}

Lignin is a complex aromatic polymer in the cell wall, which increases with plant maturity development. It consists of phenylpropane units [1], filling the gaps between cellulose and hemicellulose similarly to resin [2]. In addition, it is known that lignin content provides structural strength and rigidity for plant cell walls.

Few animal species have been reported with the ability of lignin degradation except termites and longicorn; interestingly, buffalos have recently been found to have the ability to degrade lignin. $\mathrm{Xu}$ and Zhong found that when ingesting the same forage with high fiber and low protein, buffalo showed higher dry mater intake and stronger growth performance than cattle. By conducting comparative experiments between buffalo and cattle, they reported that buffalo could degrade lignin efficiently but cattle cannot [3]; however, the studies focusing on this area are scarce. In rumen, lignin limits microbial enzymatic access to lignocellulose, which affects roughage digestibility [4] and closely disturbs the utilization extent. When the lignin content decreases, the dry matter digestibility rate significantly increases [5] because the nature of lignin's inhibits microbial enzymatic activity [6].

Lignin's main monomers are coniferyl alcohol $(\mathrm{G}), \rho$-coumaryl alcohol $(\mathrm{H})$ and sinapyl alcohol (S), and when formed by polymerization they become G-type, H-type and Stype lignin, respectively [7]. In the lignin-macromolecules complex, which originated from different classes, lignin bonds with $\mathrm{C}-\mathrm{C}$ and $\mathrm{C}-\mathrm{O}$ intermolecular bonds in a random pattern [8]. Hence, monomer variances resulted in widely different inter-unit bonds, such as $\beta-\mathrm{O}-4$ and $\beta-1$ and biphenyl $[9,10]$.

Although lignin is considered a critical limiting factor for cell-wall digestibility [11], the variations in cell-wall digestibility cannot be attributed solely to lignin content. In addition to the lignin concentration, monomer composition was a critical factor affecting fiber degradation in animal digestibility studies. However, few trials have evaluated the contribution of lignin types in altering forage utilization. During forage maturation, lignin composition in the cell wall shifts from G-type to S-type and was identified as a typical marker of cell-wall maturation. A previous study had reported that a lower S/G ratio in the Populus family was linked to a higher extent of xylose released by diluted acid hydrolysis [12]. Jung tested various forage maize and also proved that lower $\mathrm{S}$ monomer components were mainly related to more milk and meat production [13]. Through previous studies using Arabidopsis mutant [14], transgenic alfalfa [15] and the biomimetic cell wall model [16], it was reported that G-type and S-type lignin could alter cell-wall digestibility by affecting cellulolytic enzymes activity and rumen microbes action. However, Fontaine put forward a completely different opinion that the S-type content is positively correlated with maize digestibility [17]. In Arabidopsis plant tissues, the abundance of S-type lignin plays a more important role in glucose production [18].

Various roughage contains different lignin composition, which is closely linked with ruminant production. However, few reports discussed the composition of the lignin monomer and its linkage to roughage utilization. Thus, we hypothesized that the lignin monomer composition is a leading marker affecting the fiber fractions' degradation of roughage. The present study aimed to explore the functional relationship between lignin monomer composition and ruminal fiber fractions degradation in water buffalo by using different roughage sources, which may establish a novel approach for evaluating roughage's nutritional value.

\section{Materials and Methods}

\subsection{Animal and Roughage Treatment}

Three non-pregnant, non-lactating fistulated female water buffaloes (Nili-Ravi $\times$ Mediterranean, five years old, $480 \pm 20 \mathrm{~kg}$ ) bred in Jingniu Husbandry Co., Ltd., buffalo farm (Hubei, Jingmen, China) were used in this experiment. The buffaloes were fed separately with Total Mixed Ration (TMR) in order to prevent them from the interference of other animals, and they were allowed access to water freely. All animals had been well adapted to stable feeding. Eight types of roughage (rice straw, bracts, maize stalks, peanut 
vine, sweet potato vine, rice husk, maize silage and vinasse) were used in a completely randomized design. Each type of dried roughage was placed in 63 nylon bags (the size of the nylon bags is $12 \mathrm{~cm}$ long and $8 \mathrm{~cm}$ wide, and the pore sizes are $53 \mu \mathrm{m}$ ). Twenty-one nylon bags of each roughage were placed into the rumen of each buffalo $1 \mathrm{~h}$ before morning feeding at 6:00 a.m., following the principle of placing at the same time. The retention time of nylon bags in the rumen was $4 \mathrm{~h}, 8 \mathrm{~h}, 16 \mathrm{~h}, 24 \mathrm{~h}, 36 \mathrm{~h}, 48 \mathrm{~h}$ and $72 \mathrm{~h}$ after placing the bag. Three nylon bags of each roughage were taken out at each specific times. After being taken out, the nylon bags were washed, dried at $65^{\circ} \mathrm{C}$ to constant weight and the chemical compositions were determined. A control test that only placed empty nylon bags without samples into the rumen was performed in order to correct the sample's experimental error.

\subsection{Sample Analyses}

In order to analyze the fiber content in roughage. Eight types of roughage (rice straw, bracts, maize stalks, peanut vine, sweet potato vine, rice husk, maize silage and vinasse) were analyzed for neutral detergent fiber (NDF), acid detergent fiber (ADF), cellulose (CEL) and hemicellulose (HC) based on the method revised by AOAC, and HC and CEL were estimated as NDF-ADF and ADF-ADL, respectively [19]. Samples were pretreated with $\alpha$-amylase before NDF determination, and the samples were exclusive of residual ash.

The escape rate of bag sample was calculated as follows [20,21].

Escape rate of bag sample $(\%)=$ [weight of dry matter in control bag $(\mathrm{g})$ - weight of remaining matter in control bag(g)]/weight of dry matter in control bag $(\mathrm{g}) \times 100 \%$

The corrected weight was calculated as follows.

$\mathrm{CW}[$ Corrected weight in experimental bag $(\mathrm{g})]=$ weight in experimental bag $(\mathrm{g}) \times[1-$ escape rate of
bag sample $(\%)]$

The degradation amount (D) of a nutrient at a certain time point (g) was calculated as follows:

$$
\mathrm{D}=[\mathrm{Cw}-\mathrm{Bn}]-[\mathrm{Rw}-\mathrm{Rn}] \times 100 \%
$$

where $\mathrm{Bn}$ is the content of a nutrient in the residue of the control test $(\%), \mathrm{Rw}$ is the weight of residue at this culture time point $(\mathrm{g})$ and $\mathrm{Rn}$ is the content of a nutrient in residue at this culture time point (\%).

The degradation rate (Dr) of a nutrient at a certain time point (\%) was calculated as follows.

$$
\mathrm{Dr}=\mathrm{D} / \mathrm{Cw} \times \mathrm{Bn} \times 100 \%
$$

The effective degradability (ED) of feed ingredients was calculated as follows:

$$
\mathrm{ED}=\mathrm{a}+(\mathrm{b} \times \mathrm{c}) /(\mathrm{c}+\mathrm{k})
$$

where $a$ is the fast degradation part of the tested feed (\%), $b$ is the slow degradation part of the tested feed (\%), c is the degradation rate of the slow degradation part of tested feed $\left(\mathrm{h}^{-1}\right)$ and $\mathrm{k}$ is the rumen flow rate of feed to be tested $\left(\mathrm{h}^{-1}\right)\left(0.025 / \mathrm{h}^{-1}\right.$ was adopted in this test).

\subsection{Pyrolysis-Gas Chromatography/Mass Spectrometry (Py-GC-MS)}

Eight types of roughage (rice straw, bracts, maize stalks, peanut vine, sweet potato vine, rice husk, maize silage and vinasse) were analyzed for lignin composition by PyGC-MS [22]. The amount of $4.25 \mathrm{mg}$ sample of each roughage was placed in a platinum cup on a FRONTIER 3030D pyrolyzer (Frontier Laboratories Ltd, Fukushima, Japan), and pyrolysis temperature was adjusted to $500{ }^{\circ} \mathrm{C}$ [23]. After that, the samples were separated on a capillary column $(25 \mathrm{~m} \times 250 \mu \mathrm{m} \times 0.25 \mu \mathrm{m})$, and $5 \%$ Phenyl Methyl Silox was melted on the surface and then inserted in the pyrolysis outlet that was adjusted at $325^{\circ} \mathrm{C}$ 
using helium as a carrier gas. The GC program time lasted for $40.5 \mathrm{~min}$ and begun with an initial temperature of $45^{\circ} \mathrm{C}$, followed by $8 \mathrm{~h}$ at $220^{\circ} \mathrm{C}$ and, finally, the temperature increased to $280^{\circ} \mathrm{C}$. The MS program was operated at an ion source temperature of $230{ }^{\circ} \mathrm{C}$ and EM voltage of $2.141 \mathrm{kV}$, and the mass ranged from 33 to $550 \mathrm{~m} / \mathrm{z}$. The compounds were classified according to the experimental spectrum and the database map comparison. Moreover, the analysis considered the isomeric lignin monomers that had more than a single analog and were structurally similar and clustered as the same monomer. The final contents of $\mathrm{G}, \mathrm{S}$ and $\mathrm{H}$ lignin monomers were obtained.

\subsection{DNA Extraction, Sequencing of Microbial Diversity, Sequencing Data Analysis}

To avoid samples disturbance with forage, a total of six rumen contents samples named Rumen0.1, Rumen0.2, Rumen0.3, Rumen0.4, Rumen 0.5 and Rumen 0.6 were collected after $24 \mathrm{~h}$ fasting of three fistulated buffalo; two samples were collected from each buffalo rumen ("Rumen" means the samples from buffalo rumen; in order to prevent the interference from forages microorganisms, sampling should be carried out before feeding. " 0 " means fasting. The last digit represents the numbering of samples. The DNA of microorganisms in rumen content was extracted according to DNeasy PowerSoil Kit 100 manufactured by QIAGEN. The bacterial 16S rRNA V3-V4 genes were amplified by PCR using the forward primer 27F (5'-AGRGTTTGATYNTGGCTCAG-3') and the reverse primer 1492R (5'-TASGGHTACCTTGTTASGACTT- $\left.3^{\prime}\right)$. PCR amplification was performed in a total reaction volume of $30 \mu \mathrm{L}$, which contained $15 \mu \mathrm{L}$ buffer, $0.6 \mu \mathrm{L}$ Tks Gflex DNA Polymerase $(1.25 \mathrm{U} / \mu \mathrm{L}), 1 \mu \mathrm{L}$ of each primer $(5 \mathrm{pmol} / \mu \mathrm{L})$ and $1 \mu \mathrm{L}$ template DNA. PCR was set up as follows: an initial denaturation step for $5 \mathrm{~min}$ at $95{ }^{\circ} \mathrm{C}$, followed by 30 cycles of denaturation at $95{ }^{\circ} \mathrm{C}$ for $30 \mathrm{~s}$, annealing at $50{ }^{\circ} \mathrm{C}$ for $30 \mathrm{~s}$ and extension at $72{ }^{\circ} \mathrm{C}$ for $1 \mathrm{~min}$ and a final extension step at $72{ }^{\circ} \mathrm{C}$ for $7 \mathrm{~min}$. After purification, quantification and homogenization to create a sequence library, the marker gene was sequenced using the Illumina MiSeq 300PE sequencing platform and a single-molecule real-time sequencing method. All the procedures mentioned above were completed by Oebiotech Technology Co., Ltd. (Shanghai, China).

After completing Illumina MiSeq platform sequencing, the raw data were exported, and then Trimmomatic (version 0.35) [24] was used to remove low-quality data. After that, Flash (version 1.2.11) [25] was used to splice the qualified double-ended raw data in the previous step. The maximum overlap used during sequence splicing is $200 \mathrm{bp}$ in order to obtain a complete paired end sequence. split_libraries (version 1.8.0) [26] in QIIME was used to remove the sequence containing $\mathrm{N}$ base as a paired-end sequence, and it removes the sequence with a single base repeat greater than 8 and also removes the sequence with length less than $200 \mathrm{bp}$ to obtain clean tags sequence. UCHIME (version 2.4.2) software [26] was used to remove the chimera in the clean tags and for obtaining the valid tags for subsequent OTU division. Valid tags were clustered into operational taxonomic units (OTUs) at 97\% similarity using the Vsearch (version 2.4.2) [27].

\subsection{Cluster of Orthologous Groups of Proteins (COG) and Kyoto Encyclopedia of Genes and Genomes (KEGG) Analysis}

All OTUs obtained by whole gene sequencing were annotated through the COG database (http:/ / eggnogdb.embl.de/\#/app/home/ (accessed on 20 April 2020), KEGG database (http:/ / www.genome.jp/kegg/ (accessed on 20 April 2020)).

\subsection{Isolation of Lignin Degradation Microorganisms}

The rumen content is taken out and stored immediately in an anaerobic condition of $39^{\circ} \mathrm{C}$ and returned to the laboratory. The enrichment medium of lignin-degrading bacteria constitutes the following: $165 \mathrm{~mL} / \mathrm{L}$ phosphate-buffered mineral salts medium A: (per liter) $\left(\mathrm{NH}_{4}\right)_{2} \mathrm{SO}_{4}, 3.0 \mathrm{~g}, \mathrm{NaCl}, 6.0 \mathrm{~g}, \mathrm{KH}_{2} \mathrm{PO}_{4}, 3.0 \mathrm{~g}, \mathrm{CaCl}_{2} \cdot 2 \mathrm{H}_{2} \mathrm{O}, 0.4 \mathrm{~g}, \mathrm{MgSO}_{4} \cdot 7 \mathrm{H}_{2} \mathrm{O}$, $0.6 \mathrm{~g} ; 165 \mathrm{~mL} / \mathrm{L}$ phosphate-buffered mineral salts medium B: (per liter) $\mathrm{K}_{2} \mathrm{HPO}_{4} \cdot 3 \mathrm{H}_{2} \mathrm{O}$, $4.0 \mathrm{~g}, 5 \mathrm{~g} / \mathrm{L}$ sodium lignosulfonate; $170 \mathrm{~mL} / \mathrm{L}$ rumen fluid: supernatant fluid of rumen content that was filtered with four layers of gauze and centrifuged at $9000 \times g$ at $4{ }^{\circ} \mathrm{C}$ 
for $10 \mathrm{~min}$, then stored in $-20{ }^{\circ} \mathrm{C}, 0.5 \mathrm{mg} / \mathrm{L}$ copper sulfate, $1.0 \mathrm{~g} / \mathrm{L}$ tryptone, $1.0 \mathrm{~g} / \mathrm{L}$ yeast extract. Screening medium consisted of the following: $165 \mathrm{~mL} / \mathrm{L}$ phosphate-buffered mineral salts medium A, $165 \mathrm{~mL} / \mathrm{L}$ phosphate-buffered mineral salts medium B and $5.0 \mathrm{~g} / \mathrm{L}$ sodium lignosulfonate. The enriched cultures were transferred to a screening medium grown at $39^{\circ} \mathrm{C}$ in anaerobic conditions. For $10 \mathrm{~d}$, three successive transfers were performed, after which the cultures were streaked onto Luria Broth (LB) agar in order to obtain pure cultures.

\subsection{Statistical Analysis}

We analyzed the chemical composition and degradation characteristics of samples using a t-test with SPSS 19.0. The Pearson correlation coefficient in SPSS 19.0 was used to evaluate the correlation between lignin composition and fiber fractions degradation. Due to the fact that all correlations were linear, a multiple regression linear model was established. The multiple regression prediction model was defined as $y=a+b_{1} x_{1}+b_{2} x_{2}+$ $b_{3} x_{3}+\cdots+b_{m} x_{m}$, where $y$ is NDFD, ADFD, CELD, HCD and ADLD; $a$ is the random error constant; $\mathrm{b}$ is the independent variable coefficient; and $\mathrm{x}$ is $\mathrm{H}$ content, $\mathrm{S}$ content, $\mathrm{G}$ content, $\mathrm{S} / \mathrm{G}$ ratio, $\mathrm{H} / \mathrm{G}$ ratio, $\mathrm{H} / \mathrm{S}$ ratio, $(\mathrm{G}+\mathrm{S}+\mathrm{H})$ content, $\mathrm{G} /(\mathrm{G}+\mathrm{S}+\mathrm{H})$ ratio, $\mathrm{S} /(\mathrm{G}+\mathrm{S}+\mathrm{H})$ ratio and $\mathrm{H} /(\mathrm{G}+\mathrm{S}+\mathrm{H})$ ratio. The regression equation was obtained by stepwise regression of the above model variables with SPSS 19.0. Statistical significance was set at $p<0.05$ (significant difference) and $p<0.01$ (extremely significant difference).

\section{Results}

\subsection{Scanned Information of Lignin Monomers of Eight Kinds of Roughage}

As shown in Figure 1, the lignin monomer analysis reported that all the tested roughages contained three lignin monomers; $\mathrm{G}, \mathrm{S}$ and $\mathrm{H}$.

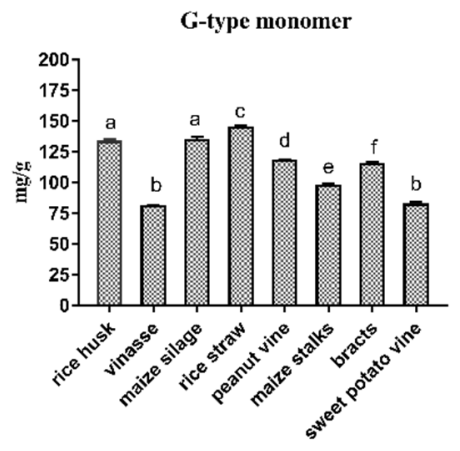

(a)

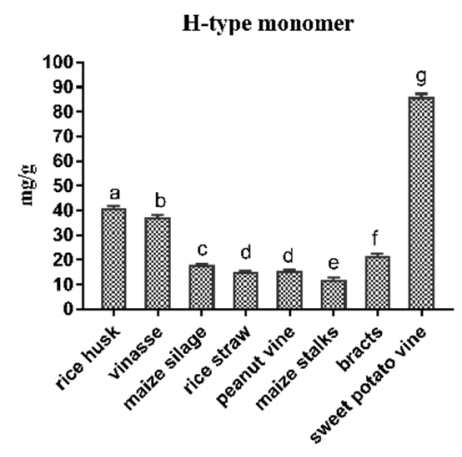

(b)

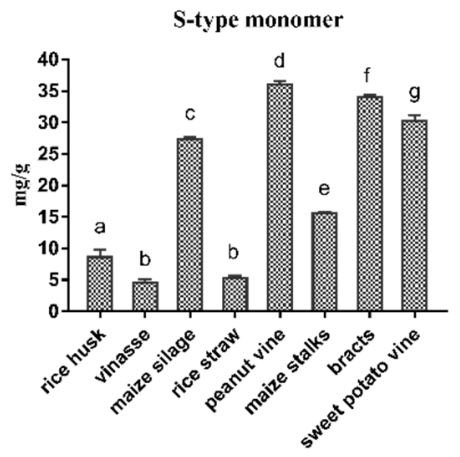

(c)

Figure 1. (a) The content of G-type monomer in 8 kinds of roughage; (b) the content of H-type monomer in 8 kinds of roughage; (c) the content of S-type monomer in 8 kinds of roughage. G means coniferyl alcohol; H means $\rho$-coumaryl alcohol; $\mathrm{S}$ means sinapyl alcohol. The different letters on the top means significant difference $(p<0.05)$; the same letters mean no significant difference $(p>0.05)$.

The higher $\mathrm{G}$ monomer types were as follows: rice straw, maize silage, rice husk, peanut vine, bracts, maize stalks, sweet potato vine and vinasse, respectively. For $\mathrm{H}$ monomer, the arrangement from rich to poor was as follows: sweet potato vine, rice husk, vinasse, bracts, maize silage, peanut vine, rice straw and maize stalks. Moreover, The higher $\mathrm{S}$ monomer types were peanut vine, bracts, sweet potato vine, maize silage, maize stalks, rice husk, rice straw and vinasse. For all tested roughages, G type was the most abundant monomer among other lignin classes, except sweet potato vine, which contained $\mathrm{H}$ unit more than $\mathrm{G}$ unit, which was the most abundant class in grass crops. Therefore, both $\mathrm{S} / \mathrm{G}$ and $\mathrm{H} / \mathrm{G}$ ratios were the highest for sweet potato vines and the lowest for the straw. 


\subsection{The Fiber Fraction Digestibility among Different Roughage Sources}

As presented in Tables 1-5, among the tested roughages for the effective degradability of NDF, ADF, ADL, CEL and HC fractions, rice husk was the lowest type. However, both sweet potato vine and bracts recorded the highest effective degradability of NDF (NDFD) and effective degradability of ADF (ADFD) coefficients. Moreover, the effective degradability of CEL (CELD) of sweet potato vine was the highest among the eight roughages; the highest effective degradability of HC (HCD) was in peanut vine, and the highest effective degradability of ADL (ADLD) was in peanut vine and maize silage, respectively.

Table 1. The effective degradability of neutral detergent fiber (NDFD) in nylon bags of 8 kinds of roughage.

\begin{tabular}{cccccc}
\hline \multirow{2}{*}{ Forages } & \multicolumn{4}{c}{ Dynamic Degradability Parameters } & \multirow{2}{*}{ NDFD (\%) } \\
\cline { 2 - 5 } & $\mathbf{a ~ ( \% )}$ & $\mathbf{b ~ ( \% )}$ & $\mathbf{c ~ ( h}^{-\mathbf{1})}$ & $\mathbf{a}+\mathbf{b} \mathbf{~ ( \% )}$ & \\
\hline rice husk & $0.53^{\mathrm{b}}$ & $7.55^{\mathrm{f}}$ & $0.014^{\mathrm{f}}$ & $8.08^{\mathrm{e}}$ & $3.22^{\mathrm{g}}$ \\
vinasse & $1.85^{\mathrm{b}}$ & $13.29^{\mathrm{f}}$ & $0.049^{\mathrm{a}}$ & $15.14^{\mathrm{e}}$ & $10.60^{\mathrm{f}}$ \\
maize silage & $3.10^{\mathrm{b}}$ & $66.64^{\mathrm{b}, \mathrm{c}}$ & $0.034^{\mathrm{b}, \mathrm{c}, \mathrm{d}}$ & $69.74^{\mathrm{b}}$ & $41.64^{\mathrm{b}}$ \\
rice straw & $2.36^{\mathrm{b}}$ & $61.86^{\mathrm{c}, \mathrm{d}}$ & $0.023^{\mathrm{d}, \mathrm{e}, \mathrm{f}}$ & $64.22^{\mathrm{b}, \mathrm{c}}$ & $31.99^{\mathrm{d}}$ \\
peanut vine & $17.08^{\mathrm{a}}$ & $30.34^{\mathrm{e}}$ & $0.040^{\mathrm{a}, \mathrm{b}}$ & $47.42^{\mathrm{d}}$ & $35.80^{\mathrm{c}}$ \\
maize stalks & $0.43^{\mathrm{b}}$ & $66.05^{\mathrm{b}, \mathrm{c}}$ & $0.027^{\mathrm{c}, \mathrm{d}, \mathrm{e}}$ & $66.48^{\mathrm{b}}$ & $34.70^{\mathrm{c}}$ \\
bracts & $1.02^{\mathrm{b}}$ & $70.65^{\mathrm{a}, \mathrm{b}}$ & $0.043^{\mathrm{a}, \mathrm{b}}$ & $71.67^{\mathrm{a}, \mathrm{b}}$ & $44.49^{\mathrm{a}}$ \\
sweet potato vine & $2.67^{\mathrm{b}}$ & $68.86^{\mathrm{a}, \mathrm{b}, \mathrm{c}}$ & $0.039^{\mathrm{a}, \mathrm{b}, \mathrm{c}}$ & $71.53^{\mathrm{a}, \mathrm{b}}$ & $44.64^{\mathrm{a}}$ \\
\hline
\end{tabular}

Notes: Means in the same column with different superscripts differ $(p<0.05)$.

Table 2. The effective degradability of acid detergent fiber (ADFD) in nylon bags of 8 kinds of roughage.

\begin{tabular}{cccccc}
\hline \multirow{2}{*}{ Forages } & \multicolumn{3}{c}{ Dynamic Degradability Parameters } & \multirow{2}{*}{ ADFD (\%) } \\
\cline { 2 - 4 } & $\mathbf{a ~ ( \% )}$ & $\mathbf{b ~ ( \% )}$ & $\mathbf{c ~ ( h}^{\mathbf{- 1})}$ & $\mathbf{a}+\mathbf{b} \mathbf{~ ( \% )}$ & \\
\hline rice husk & $0.86^{\mathrm{d}, \mathrm{e}, \mathrm{f}}$ & $6.05^{\mathrm{e}}$ & $0.021^{\mathrm{c}, \mathrm{d}}$ & $6.91^{\mathrm{f}}$ & $3.58^{\mathrm{h}}$ \\
vinasse & $5.62^{\mathrm{a}}$ & $11.91^{\mathrm{e}}$ & $0.032^{\mathrm{b}, \mathrm{c}}$ & $17.53^{\mathrm{e}}$ & $12.26^{\mathrm{g}}$ \\
maize silage & $1.25^{\mathrm{c}, \mathrm{d}}$ & $70.20^{\mathrm{b}, \mathrm{c}}$ & $0.032^{\mathrm{b}, \mathrm{c}}$ & $71.45^{\mathrm{b}, \mathrm{c}}$ & $40.32^{\mathrm{b}}$ \\
rice straw & $0.24^{\mathrm{f}}$ & $66.97^{\mathrm{b}, \mathrm{c}}$ & $0.021^{\mathrm{c}, \mathrm{d}}$ & $67.21^{\mathrm{c}}$ & $30.73^{\mathrm{e}}$ \\
peanut vine & $3.48^{\mathrm{b}}$ & $41.08^{\mathrm{d}}$ & $0.082^{\mathrm{a}}$ & $44.56^{\mathrm{d}}$ & $34.86^{\mathrm{c}, \mathrm{d}}$ \\
maize stalks & $0.33^{\mathrm{e}, \mathrm{f}}$ & $66.01^{\mathrm{c}}$ & $0.026^{\mathrm{c}, \mathrm{d}}$ & $66.34^{\mathrm{c}}$ & $33.70^{\mathrm{d}}$ \\
bracts & $0.95^{\mathrm{d}, \mathrm{e}}$ & $73.63^{\mathrm{b}}$ & $0.044^{\mathrm{b}}$ & $74.58^{\mathrm{b}}$ & $47.84^{\mathrm{a}}$ \\
sweet potato vine & $1.69^{\mathrm{c}}$ & $85.35^{\mathrm{a}}$ & $0.031^{\mathrm{b}, \mathrm{c}, \mathrm{d}}$ & $87.04^{\mathrm{a}}$ & $48.59^{\mathrm{a}}$ \\
\hline
\end{tabular}

Notes: Means in the same column with different superscripts differ $(p<0.05)$.

Table 3. The effective degradability of acid detergent lignin (ADLD) in nylon bags of 8 kinds of roughage.

\begin{tabular}{cccccc}
\hline \multirow{2}{*}{ Forages } & \multicolumn{3}{c}{ Dynamic Degradability Parameters } & \multirow{2}{*}{ ADLD (\%) } \\
\cline { 2 - 4 } & $\mathbf{a ~ ( \% )}$ & $\mathbf{b ~ ( \% )}$ & $\mathbf{c ~ ( h}^{\mathbf{- 1})}$ & $\mathbf{a}+\mathbf{b} \mathbf{~ ( \% )}$ & \\
\hline rice husk & $0.23^{\mathrm{d}, \mathrm{e}}$ & $10.52^{\mathrm{e}}$ & $0.034^{\mathrm{b}}$ & $10.75^{\mathrm{e}, \mathrm{f}}$ & $6.29^{\mathrm{f}}$ \\
vinasse & $1.99^{\mathrm{a}}$ & $12.93^{\mathrm{d}, \mathrm{e}}$ & $0.026^{\mathrm{b}, \mathrm{c}}$ & $14.92^{\mathrm{d}, \mathrm{e}}$ & $8.38^{\mathrm{d}, \mathrm{e}}$ \\
maize silage & $0.85^{\mathrm{b}}$ & $38.14^{\mathrm{a}}$ & $0.015^{\mathrm{c}}$ & $38.99^{\mathrm{a}}$ & $14.78^{\mathrm{a}}$ \\
rice straw & $0.39^{\mathrm{c}, \mathrm{d}, \mathrm{e}}$ & $26.61^{\mathrm{b}}$ & $0.020^{\mathrm{b}, \mathrm{c}}$ & $26.99^{\mathrm{b}}$ & $12.05^{\mathrm{b}}$ \\
peanut vine & $2.37^{\mathrm{a}}$ & $17.08^{\mathrm{c}, \mathrm{d}}$ & $0.074^{\mathrm{a}}$ & $19.45^{\mathrm{c}, \mathrm{d}}$ & $15.04^{\mathrm{a}}$ \\
maize stalks & $0.77^{\mathrm{b}, \mathrm{c}}$ & $23.00^{\mathrm{b}}$ & $0.024^{\mathrm{b}, \mathrm{c}}$ & $23.77^{\mathrm{b}, \mathrm{c}}$ & $11.97^{\mathrm{b}}$ \\
bracts & $0.12^{\mathrm{e}}$ & $21.80^{\mathrm{b}, \mathrm{c}}$ & $0.020^{\mathrm{b}, \mathrm{c}}$ & $21.92^{\mathrm{c}}$ & $9.78^{\mathrm{c}, \mathrm{d}}$ \\
sweet potato vine & $0.66^{\mathrm{b}, \mathrm{c}, \mathrm{d}}$ & $9.25^{\mathrm{e}}$ & $0.061^{\mathrm{b}}$ & $9.91^{\mathrm{f}}$ & $7.22^{\mathrm{e}, \mathrm{f}}$ \\
\hline
\end{tabular}

Notes: Means in the same column with different superscripts differ $(p<0.05)$. 
Table 4. The effective degradability of cellulose (CELD) in nylon bags of 8 kinds of roughage.

\begin{tabular}{cccccc}
\hline \multirow{2}{*}{ Forages } & \multicolumn{3}{c}{ Dynamic Degradability Parameters } & \multirow{2}{*}{ CELD (\%) } \\
\cline { 2 - 4 } & $\mathbf{a ~ ( \% )}$ & $\mathbf{b ~ ( \% )}$ & $\mathbf{c ~ ( h ) ~}^{\mathbf{- 1})}$ & $\mathbf{a}+\mathbf{b} \mathbf{~ ( \% )}$ & \\
\hline rice husk & $2.19^{\mathrm{c}, \mathrm{d}}$ & $7.21^{\mathrm{f}}$ & $0.007^{\mathrm{d}}$ & $9.40^{\mathrm{f}}$ & $3.70^{\mathrm{h}}$ \\
vinasse & $6.95^{\mathrm{a}}$ & $12.75^{\mathrm{f}}$ & $0.021^{\mathrm{c}}$ & $19.70^{\mathrm{e}}$ & $11.99 \mathrm{~g}$ \\
maize silage & $1.38^{\mathrm{d}, \mathrm{e}}$ & $70.32^{\mathrm{c}}$ & $0.036^{\mathrm{b}}$ & $71.70^{\mathrm{b}}$ & $42.63^{\mathrm{c}}$ \\
rice straw & $1.14^{\mathrm{e}}$ & $76.74^{\mathrm{b}}$ & $0.022^{\mathrm{c}}$ & $77.88^{\mathrm{b}}$ & $36.92^{\mathrm{d}}$ \\
peanut vine & $4.41^{\mathrm{b}}$ & $52.15^{\mathrm{e}}$ & $0.093^{\mathrm{a}}$ & $56.55^{\mathrm{d}}$ & $45.45^{\mathrm{b}}$ \\
maize stalks & $1.18^{\mathrm{e}}$ & $64.03^{\mathrm{d}}$ & $0.028^{\mathrm{b}, \mathrm{c}}$ & $65.21^{\mathrm{c}}$ & $34.83^{\mathrm{e}}$ \\
bracts & $0.72^{\mathrm{e}}$ & $86.65^{\mathrm{a}}$ & $0.023^{\mathrm{b}, \mathrm{c}}$ & $87.37^{\mathrm{a}}$ & $42.56^{\mathrm{c}}$ \\
$\begin{array}{c}\text { sweet potato } \\
\text { vine }\end{array}$ & $2.85^{\mathrm{c}}$ & $82.94^{\mathrm{a}}$ & $0.032^{\mathrm{b}, \mathrm{c}}$ & $85.79^{\mathrm{a}}$ & $49.18^{\mathrm{a}}$ \\
\hline
\end{tabular}

Notes: Means in the same column with different superscripts differ $(p<0.05)$.

Table 5. The effective degradability of hemicellulose (HCD) in nylon bags of 8 kinds of roughage.

\begin{tabular}{cccccc}
\hline \multirow{2}{*}{ Forages } & \multicolumn{4}{c}{ Dynamic Degradability Parameters } & \multirow{2}{*}{ HCD (\%) } \\
\cline { 2 - 5 } & $\mathbf{a ~ ( \% )}$ & $\mathbf{b ~ ( \% )}$ & $\mathbf{c ~ ( \mathbf { h } ^ { - \mathbf { 1 } } )}$ & $\mathbf{a}+\mathbf{b ~ ( \% )}$ & \\
\hline rice husk & $0.79^{\mathrm{c}}$ & $28.05^{\mathrm{f}, \mathrm{g}}$ & $0.015^{\mathrm{d}}$ & $28.83^{\mathrm{f}}$ & $11.05^{\mathrm{g}}$ \\
vinasse & $13.25^{\mathrm{b}}$ & $23.63^{\mathrm{g}}$ & $0.043^{\mathrm{a}, \mathrm{b}}$ & $36.87^{\mathrm{e}, \mathrm{f}}$ & $28.23^{\mathrm{e}}$ \\
maize silage & $2.84^{\mathrm{c}}$ & $63.54^{\mathrm{b}, \mathrm{c}}$ & $0.055^{\mathrm{a}}$ & $66.37^{\mathrm{b}, \mathrm{c}, \mathrm{d}}$ & $46.54^{\mathrm{b}}$ \\
rice straw & $1.73^{\mathrm{c}}$ & $54.49^{\mathrm{d}}$ & $0.038^{\mathrm{a}, \mathrm{b}, \mathrm{c}}$ & $56.22^{\mathrm{d}}$ & $34.60^{\mathrm{d}}$ \\
peanut vine & $32.67^{\mathrm{a}}$ & $36.23^{\mathrm{e}, \mathrm{f}}$ & $0.031^{\mathrm{b}, \mathrm{c}, \mathrm{d}}$ & $68.90^{\mathrm{b}, \mathrm{c}}$ & $51.05^{\mathrm{a}}$ \\
maize stalks & $1.01^{\mathrm{c}}$ & $75.80^{\mathrm{a}}$ & $0.021^{\mathrm{c}, \mathrm{d}}$ & $76.80^{\mathrm{a}, \mathrm{b}}$ & $35.41^{\mathrm{d}}$ \\
bracts & $3.72^{\mathrm{c}}$ & $76.24^{\mathrm{a}}$ & $0.027^{\mathrm{b}, \mathrm{c}, \mathrm{d}}$ & $79.96^{\mathrm{a}}$ & $43.18^{\mathrm{c}}$ \\
sweet potato vine & $3.67^{\mathrm{c}}$ & $66.69^{\mathrm{b}}$ & $0.036^{\mathrm{b}, \mathrm{c}}$ & $70.35^{\mathrm{a}, \mathrm{b}}$ & $42.63^{\mathrm{c}}$ \\
\hline
\end{tabular}

Notes: Means in the same column with different superscripts differ $(p<0.05)$.

\subsection{Correlation between Lignin Composition and Rumen Digestibility of Fiber}

As shown in Table 6, there was no significant correlation between the H-type lignin, G-type lignin content and the NDFD, ADFD, CELD and HCD. There was no significant correlation between G-type lignin and ADLD. However, there was a highly significant positive correlation between the S-type lignin content and all the measured coefficients of NDFD, ADFD, CELD, HCD and ADLD. S, S/G and S/ (G+S+H) showed a significant positive correlation with NDFD, ADFD, CELD and HCD, although H/S significantly correlated negatively. ADLD was negatively linked to $\mathrm{H}, \mathrm{H} / \mathrm{G}, \mathrm{H} / \mathrm{S}$ and $\mathrm{H} /(\mathrm{G}+\mathrm{S}+\mathrm{H})$, and it was positively linked to S-type lignin content and $\mathrm{S} /(\mathrm{G}+\mathrm{S}+\mathrm{H})$.

Table 6. Correlation between lignin composition and fiber fractions degradation (r).

\begin{tabular}{|c|c|c|c|c|c|c|c|c|c|c|}
\hline & \multicolumn{10}{|c|}{ Pearson $r$} \\
\hline & G & S & $\mathbf{H}$ & $\mathrm{G}+\mathrm{S}+\mathrm{H}$ & S/G & H/G & $\mathrm{H} / \mathrm{S}$ & $\mathrm{G} /(\mathrm{G}+\mathrm{S}+\mathrm{H})$ & $\mathrm{S} /(\mathrm{G}+\mathrm{S}+\mathrm{H})$ & $\mathrm{H} /(\mathrm{G}+\mathrm{S}+\mathrm{H})$ \\
\hline NDFD & 0.060 & $0.706 *$ & -0.113 & 0.295 & $0.672 *$ & -0.041 & -0.793 * & -0.126 & 0.704 * & -0.269 \\
\hline ADFD & -0.011 & 0.712 * & 0.033 & 0.367 & 0.723 * & 0.103 & $-0.745^{*}$ & -0.247 & 0.690 * & -0.135 \\
\hline CELD & 0.065 & 0.710 * & -0.040 & 0.368 & 0.703 * & 0.030 & $-0.788^{*}$ & -0.170 & 0.693 * & -0.218 \\
\hline HCD & 0.008 & 0.765 * & -0.060 & 0.325 & $0.732 *$ & 0.018 & $-0.767 *$ & -0.209 & 0.753 * & -0.211 \\
\hline ADLD & 0.274 & $0.542 *$ & $-0.633 *$ & -0.065 & 0.318 & -0.593 * & $-0.695 *$ & 0.307 & $0.626^{*}$ & $-0.678^{*}$ \\
\hline
\end{tabular}

Notes: G means coniferyl alcohol; $\mathrm{H}$ means $\rho$-coumaryl alcohol; S means sinapyl alcohol; NDFD means effective degradability of neutral detergent fiber; ADFD means effective degradability of acid detergent fiber; ADLD means effective degradability of acid detergent lignin; CELD means effective degradability of cellulose; HCD means effective degradability of hemicellulose. * means $p<0.01$. Data without * means $p>0.05$.

\subsection{Multiple Regression Model among Lignin Composition and Fiber Fractions Degradation}

The fiber-fractions' degradation could be predicted using stepwise regression through the model presented in Table 7. The essence of stepwise regression is to establish an 
"optimal" multiple linear regression model; thus, only the monomers representing " $\mathrm{x}$ " that have a significant impact on the fiber fractions degradation are retained, and other monomers representing " $x$ " that have no significant impact are excluded. Therefore, the monomers representing " $x$ " in different models are different. The ADLD model could explain the degradation $\left(\mathrm{R}^{2}\right)$ of 0.758 , followed by HCD (0.709), ADFD (0.678), NDFD (0.628) and CELD (0.620). According to these models, the factors affecting fiber fractions degradation could accurately describe and predict the ruminal digestibility of different forages with a similar approach.

Table 7. Multiple regression models among lignin composition parameters and fiber fractions degradation (stepwise regression).

\begin{tabular}{cccc}
\hline & Optimal Models & $\mathbf{R}^{\mathbf{2}}$ & $p$-Value \\
\hline NDFD & $\mathrm{Y}=0.647-0.071 \times \mathrm{H} / \mathrm{S}$ & 0.628 & $<0.01$ \\
ADFD & $\mathrm{Y}=0.427-0.045 \times \mathrm{H} / \mathrm{S}+0.826 \times \mathrm{S} / \mathrm{G}$ & 0.678 & $<0.01$ \\
ADLD & $\mathrm{Y}=0.161-1.918 \times \mathrm{H}+3.152 \times \mathrm{S}$ & 0.758 & $<0.01$ \\
CELD & $\mathrm{Y}=0.724-0.081 \times \mathrm{H} / \mathrm{S}$ & 0.620 & $<0.01$ \\
HCD & $\mathrm{Y}=0.522-0.038 \times \mathrm{H} / \mathrm{S}+0.649 \times \mathrm{S} / \mathrm{G}$ & 0.709 & $<0.01$ \\
\hline
\end{tabular}

Notes: $\mathrm{G}$ means coniferyl alcohol; $\mathrm{H}$ means $\rho$-coumaryl alcohol; S means sinapyl alcohol; NDFD means effective degradability of neutral detergent fiber; ADFD means effective degradability of acid detergent fiber; ADLD means effective degradability of acid detergent lignin; CELD means effective degradability of cellulose; HCD means effective degradability of hemicellulose. $\mathrm{R}^{2}$ means the coefficient of determination.

\subsection{Composition of Rumen Microorganisms}

As shown in Figure 2, at the phylum level (the results only show the top 15 in relative abundance), the rumen microorganisms are almost clustered in Bacteroidetes and Firmicutes. The most dominant phylum is Bacteroidetes, following by Firmicutes, Fibrobacteres, Spirochaetes, Proteobacteria and Tenericutes. At the bacterial genus level (the results only show the top 15 in relative abundance), the strain with absolute predominance in the microbial composition of rumen flora is Prevotella_1, followed by Rikenellaceae_RC9_gut_group, Ruminococcaceae_UCG-011, Fibrobacter, Ruminococcus_1 and Saccharofermentans.

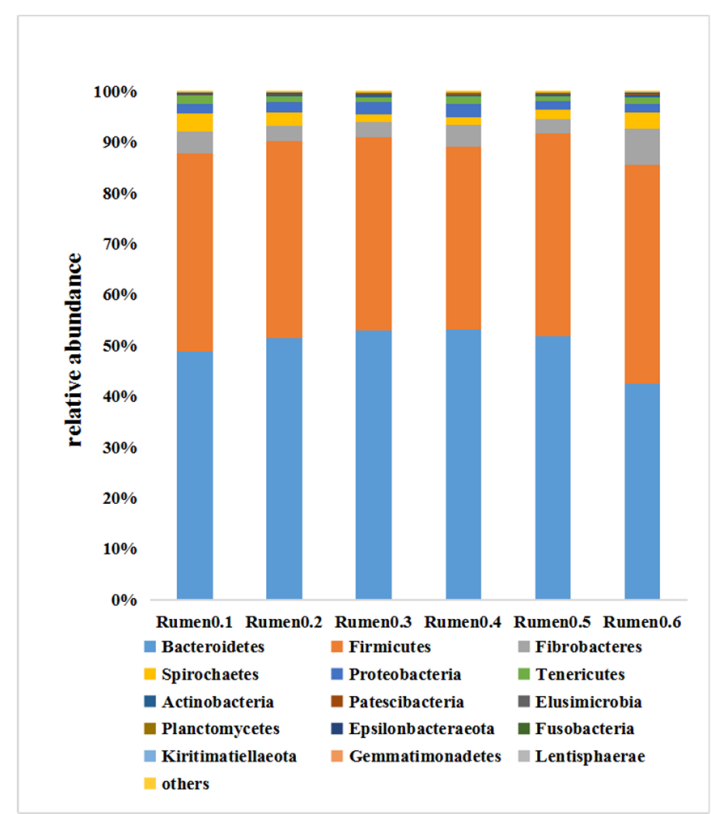

(a)

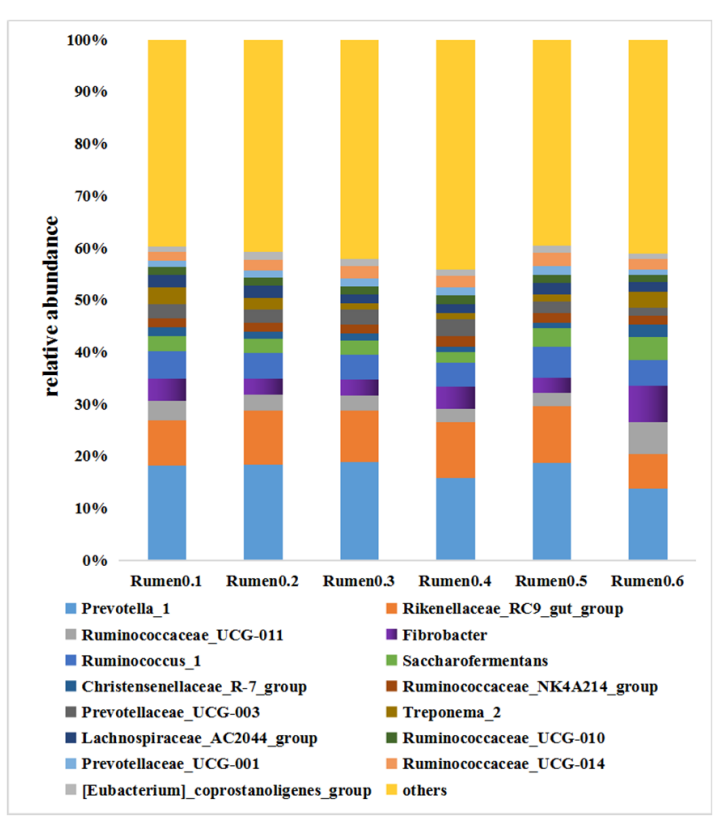

(b)

Figure 2. (a) Composition of rumen microorganisms at phylum level; (b) composition of rumen microorganisms at genus level. Notes: Rumen0.1, Rumen0.2, Rumen0.3, Rumen0.4, Rumen0.5 and Rumen0.6 represent the name of six rumen contents samples. 


\subsection{Annotation Results of Rumen Microorganisms in COG and KEGG Database}

As shown in Figure 3, the rumen flora is enriched in 24 sorts of COG functions. The top three are general function predictions only $(\mathrm{R})$, transcription $(\mathrm{K})$ and carbohydrate transport and metabolism $(\mathrm{G})$. The last four with significantly less enriched functions are cytoskeleton (Z), chromatin structure and dynamics (B), RNA processing and modification (A) and extracellular structures (W).

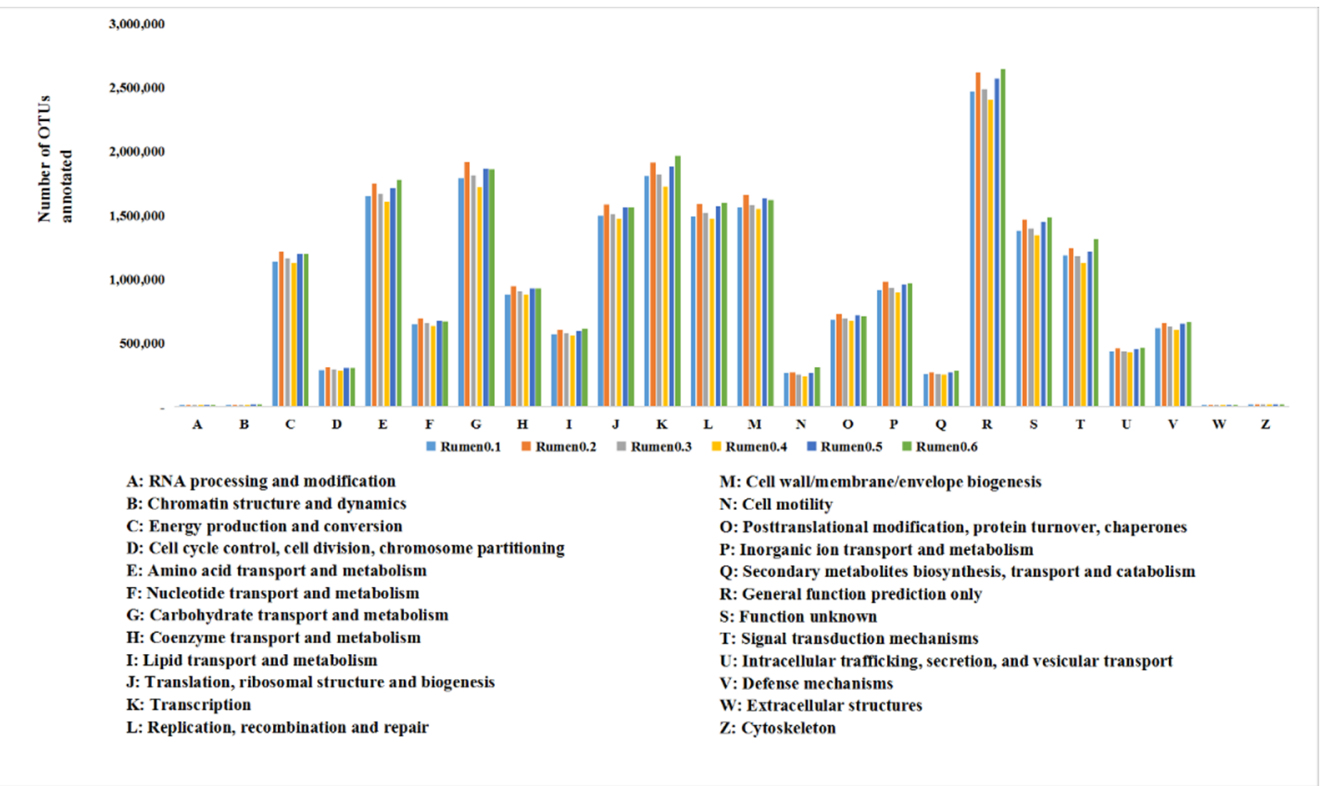

Figure 3. Prediction of Cluster of Orthologous Groups of proteins (COG) function of rumen flora. Notes: Rumen0.1, Rumen0.2, Rumen0.3, Rumen0.4, Rumen0.5 and Rumen0.6 represent the name of six rumen contents samples. Details about the samples are shown in Table A1 (Appendix A).

The annotation results of rumen microorganisms on the secondary pathway of the KEGG database are shown in Figure 4, which are mainly involved in membrane transport, amino acid metabolism, carbohydrate metabolism, replication and repair, translation and energy metabolism. Rumen microorganisms are enriched in KEGG annotate relative to metabolic pathways related to aromatic compound degradation, as shown in Table 8, including aminobenzoate degradation, benzoate degradation, ethylbenzene degradation, fluorobenzoate degradation, metabolism of xenobiotics by cytochrome P450, naphthalene degradation, phenylalanine metabolism, styrene degradation and xylene degradation.

Table 8. Number of operational taxonomic units (OTUs) relate to aromatic compounds in Kyoto Encyclopedia of Genes and Genomes (KEGG) function annotation.

\begin{tabular}{|c|c|c|c|c|c|c|}
\hline \multirow[b]{2}{*}{ KEGG Pathways } & \multicolumn{6}{|c|}{ Number of OTUs Annotated } \\
\hline & Rumen0.1 & Rumen0.2 & Rumen 0.3 & Rumen 0.4 & Rumen0.5 & Rumen0.6 \\
\hline Aminobenzoate degradation & 25,548 & 26,834 & 25,353 & 25,088 & 26,189 & 28,438 \\
\hline Benzoate degradation & 45,910 & 48,245 & 46,045 & 44,336 & 48,005 & 52,353 \\
\hline Ethylbenzene degradation & 13,261 & 13,902 & 13,114 & 12,654 & 13,594 & 14,036 \\
\hline Fluorobenzoate degradation & 822 & 702 & 714 & 855 & 723 & 1363 \\
\hline $\begin{array}{l}\text { Metabolism of xenobiotics by } \\
\text { cytochrome P450 }\end{array}$ & 3351 & 3295 & 3141 & 3374 & 3290 & 4459 \\
\hline Naphthalene degradation & 30,066 & 32,269 & 30,550 & 29,516 & 31,710 & 31,856 \\
\hline Phenylalanine metabolism & 41,657 & 43,802 & 41,547 & 40,372 & 42,813 & 44,766 \\
\hline Styrene degradation & 2867 & 2922 & 2774 & 2634 & 2662 & 3714 \\
\hline Xylene degradation & 9032 & 9499 & 9073 & 8614 & 9848 & 10,695 \\
\hline
\end{tabular}

Notes: Rumen0.1, Rumen0.2, Rumen0.3, Rumen0.4, Rumen0.5 and Rumen0.6 represent the name of six rumen contents samples. Details about the samples are shown in Table A1 (Appendix A). 


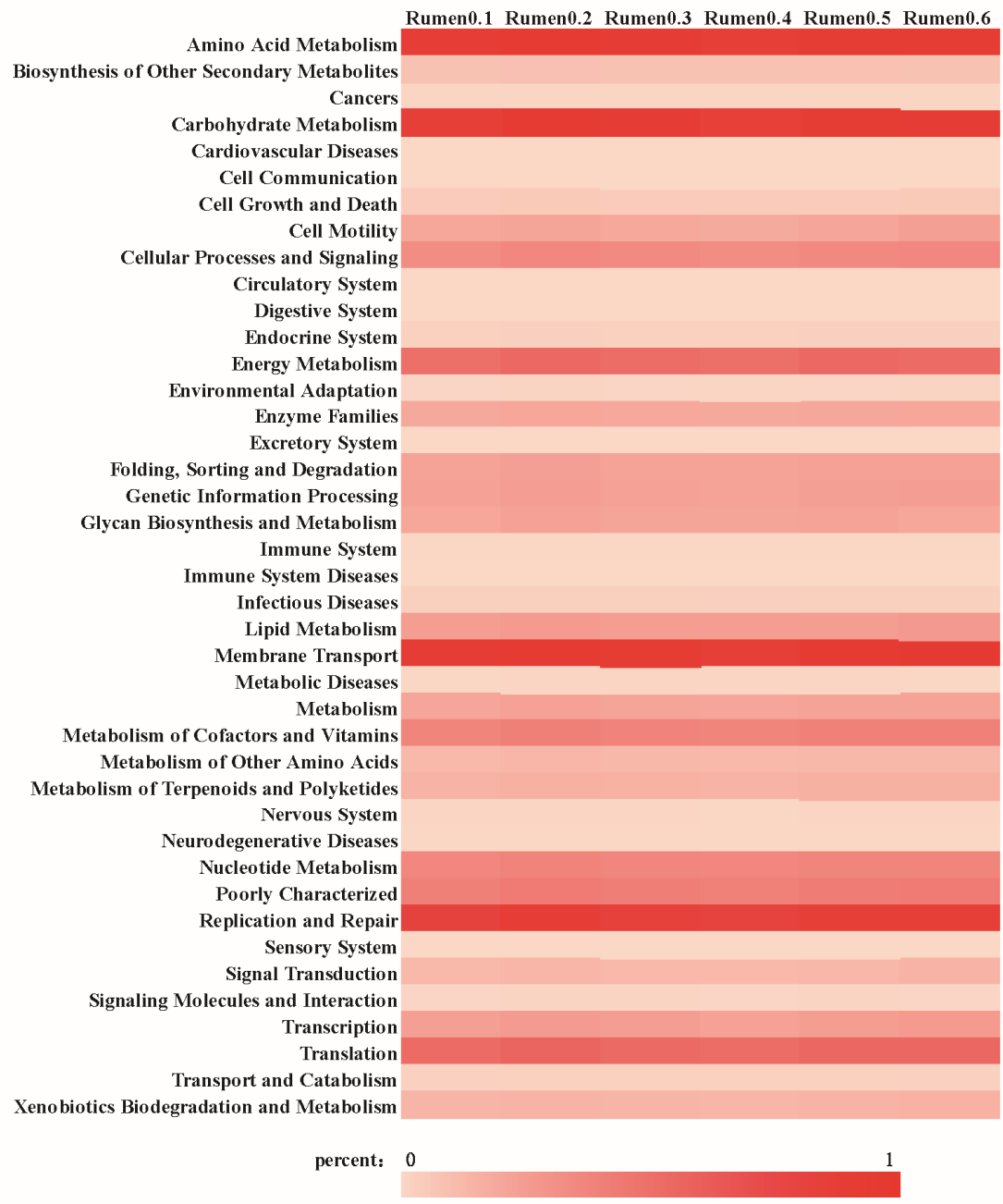

Figure 4. Prediction of rumen flora in the secondary pathway of Kyoto Encyclopedia of Genes and Genomes (KEGG). Notes: Rumen0.1, Rumen0.2, Rumen0.3, Rumen0.4, Rumen0.5 and Rumen0.6 represent the name of six rumen contents samples. Details about the samples are shown in Table A1 (Appendix A).

\subsection{Isolation of Lignin Degradation Microorganisms of Buffalo Rumen}

The collected rumen contents were repeatedly isolated and screened with a lignin screening medium. After purification and culture, one fungus and five bacterial strains were obtained. The results are shown in Figure 5 and named F9, B20, B36, B44, B46 and B58, respectively. The initial growth stage of fungus $\mathrm{F} 9$ is white filamentous, the edge is radial and the mycelium is long. With the increase in culture days, the mycelium color gradually turns gray, the mycelium circle also expands and dark spores grow. At first, strain B20 had a small colony, white and opaque texture, regular edges, smooth and moist, slow growth and light red color after $4-5$ days of growth. Strain B36 is a thin white colony with a dry surface texture that is difficult to pick up. The strain B36 center is convex, and the shape is a concentric circle. Strains B44 and B46 were white dots and grew into sticky colonies with neat edges and yellowish color. Strain B58 grew from dots to regular circular colonies, with light yellow color, smooth, moist and sticky surface; neat edges; and gradually irregular edges after $4-5$ days of growth. 


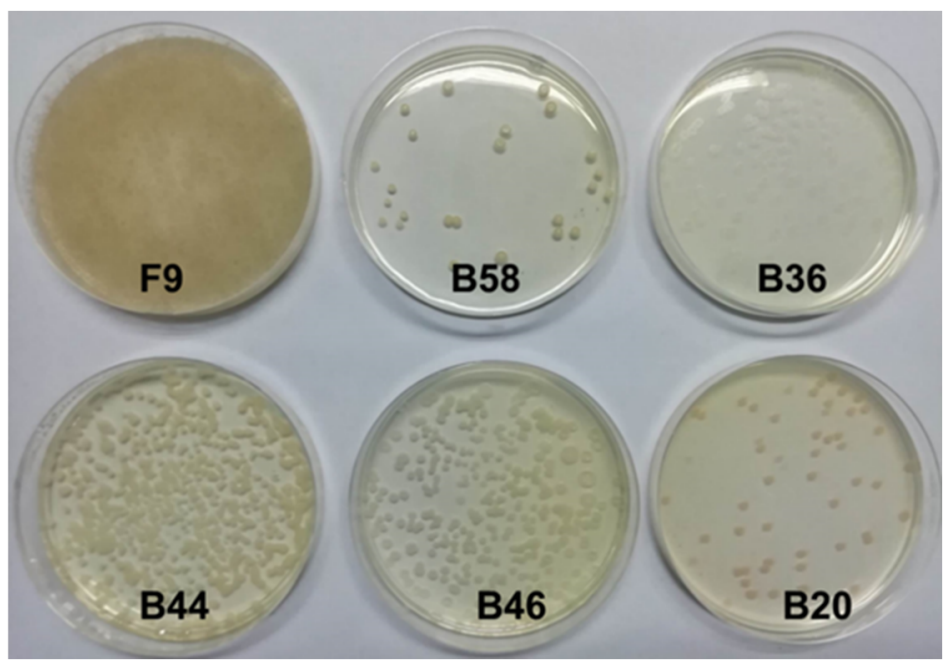

Figure 5. Colonies with lignin degradation potential screened from buffalo rumen. Notes: F9, B20, B36, B44, B46 and B58 mean the numbering of six strains. " $F$ " and " $B$ " on the strain samples originate from fungal and bacterial initials, and the numbers on the strain samples represent the numbering of retained strains with lignin degradation capacity.

\section{Discussion}

Lignin is a significant contributor to roughage structure and the main target for examining forages digestibility improvements. Previous reports discussed the connection between lignin monomer composition and degradation rate; however, it was mainly in the biomass energy field, paper making and other fields [18,28]. In animal nutrition, the lignin role in depressing fiber fractions utilization in the ruminant digestive tract is usually attributed to lignin concentration. However, our findings suggested that the lignin monomer composition of different forages is another critical factor for the burden feed utilization in buffalo rumen.

Interestingly, the S-type content significantly correlated with the degradation of fiber components, affecting NDFD, ADFD and CELD. It was believed that the deposition of S-type lignin monomer content in plant cell walls promotes lignification development [29], which affects the degradation rate of fiber fractions in the rumen. Jung and Deetz also reported that S-type lignin is more linear in structure than G-type and H-type in the lignin monomer model and that S-type can extend to the secondary wall of the plant cell wall and become a polysaccharide defender against its digestion activity [13]. Therefore, the present findings support that the existence of S-type lignin may be a significant barrier against roughage digestibility.

Although the gel-state 2D-NMR analysis reported a phenomenon when the molar ratio of S-type to G-type lignin in the cell wall is 4:3, the degree of lignification would decrease [30]. Another study in Arabidopsis reported that the richness of S-type lignin plays a more significant role in glucose yield than G-lignin-rich in plant tissues [28]. Therefore, ferulate cross-linking of arabinoxylans to lignin in the cell wall could restrict structural polysaccharides enzymatic degradation, limiting the utilization of crops as feedstuffs. It has been reported that a 70\% reduction in ferulate-lignin cross-linking would increase carbohydrate solubilization by $24-46 \%$ and enhance cell wall degradability [31,32]. Moreover, the S-type lignin can interfere with ferulate copolymerization with lignin [33], which had minimal effects on cell wall lignification and could promote the utilization of the roughage.

Some previous studies contradict this experiment's findings that support the effect of S-type lignin on fiber fractions degradation. This experiment was conducted in vivo using buffalo rumen; such experimental conditions did not exist before, presenting a new view on the effect of lignin composition on feed utilization.

Many factors determine the degradation rate of fiber fractions in the rumen, in addition to the widely accepted lignin concentration, lignin monomer composition, ferulic acid 
cross-linking, cellulose crystallinity, cellulose polymerization degree and hemicellulose composition, which also have significant roles [34-36]. In this study, the regression degree of lignin monomer composition parameters on the degradation rate of fiber components is significant, and the interpretation rate $\left(R^{2}\right)$ is about $70 \%$. Regarding other factors, lignin monomer composition has a chief influence on the fiber fractions' degradation rate. In this experiment, the effect of lignin on the degradation rate of fiber fraction in roughage was only considered from the aspect of lignin monomer composition; not all the influencing factors were not included in the research scope. Although the prediction model obtained did not reach a very high correlation, it still can be accepted as a reference standard for predicting the fiber fractions degradation rate for roughage.

Lignin is a structural stability polymer, and it has not been reported that mammals can degrade and utilize lignin. In addition to biodegradable fiber, the results also proved the ADL degradability in eight kinds of roughage by buffalo. The above results are consistent with Xu and Zhong's study [3]. They brought forward that buffalo had lignin degradation by comparing buffalo and cattle and found that the ADL degradation rate of rice straw in buffalo rumen was significantly higher than that in cattle rumen. This experiment directly verified the ability of buffalo to degrade $A D L$, which has not been found in other mammals. The buffalo showed stronger roughage resistance [37]. A previous study demonstrated that there exists a unique rumen microflora in buffalo rumen. Wanapat proved that the total number of bacteria, cellulolytic, proteolytic and amylolytic bacteria of buffalo rumen was significantly higher than cattle fed with the same feedstuff of rice straw [38]. Wanapat put forward the opinion that the unique microorganisms of buffalo rumen are the reasons for why they exhibit outstanding growth performance compared to cattle. In this study, several microorganisms with lignin degradation potential were isolated from buffalo rumen with lignin degradation ability. This result is consistent with Wang's research which also isolated strains with lignin degradation potential in buffalo rumen [39]. The study seems to point out that rumen microorganisms were the underlying mechanisms of lignin degradation. In this experiment, we found that Bacteroidetes and Firmicutes are the most dominant bacteria among buffalo rumen microorganisms, and their relative abundance accounts for nearly $90 \%$. It is reported that some bacteria of Firmicutes, Proteus and actinomycetes are the main bacteria with lignin degradation function [40]. The rumen microbial composition of Firmicutes accounts for a large proportion, and the relative abundance of Proteobacteria is $2.02 \%$, but Actinomycetes numbered very few.

The annotation results of rumen microorganisms in the KEGG database showed that many microorganisms were enriched in the degradation pathway of aromatic compounds. Lignin is an aromatic polymer with a three-dimensional structure, and its basic unit is phenylalanine. The degradation of aromatic compounds is closely related to lignin degradation. Among them include the pathways of phenylalanine metabolism and metabolism of xenobiology by cytochrome P450. Cytochrome P450 is a verified enzyme involved in lignin degradation [41]. In the pathway of aminobenzoate degradation, existing methyl gallate metabolic and protocatechuate metabolic processes are present, which are the vital pathways that strains follow for degrading lignin [42]. Buffalo rumen microorganisms may degrade lignin through this series of pathways, which needs further investigation.

\section{Conclusions}

It was concluded that lignin monomer composition is an important factor affecting fiber fractions degradation in roughage, and the prediction models are as follows: NDFD = $0.647-0.071 \times \mathrm{H} / \mathrm{S}\left(\mathrm{R}^{2}=0.628, p<0.01\right), \mathrm{ADFD}=0.427-0.045 \times \mathrm{H} / \mathrm{S}+0.826 \times \mathrm{S} / \mathrm{G}$ $\left(\mathrm{R}^{2}=0.678, p<0.01\right), \mathrm{ADLD}=0.161-1.918 \times \mathrm{H}+3.152 \times \mathrm{S}\left(\mathrm{R}^{2}=0.758, p<0.01\right), \mathrm{CELD}$ $=0.724-0.081 \times \mathrm{H} / \mathrm{S}\left(\mathrm{R}^{2}=0.620, p<0.01\right)$ and $\mathrm{HCD}=0.522-0.038 \times \mathrm{H} / \mathrm{S}+0.649 \times$ $\mathrm{S} / \mathrm{G}\left(\mathrm{R}^{2}=0.709, p<0.01\right)$. This experiment fills in the blanks of relationship between lignin composition and ruminal fiber fractions degradation. The result provides a new approach for evaluating roughage feedstuffs and for improving the understanding of fiber utilization in ruminants. Moreover, we found that the lignin degradation ability of buffalo is based 
on its unique rumen microorganisms, but the specific degradation mechanism needs to be further studied.

Author Contributions: X.L., L.Y. and H.X. conceived and designed the study. H.Z., H.X., Z.M. and L.C. extracted the data. H.Z., J.Z. and Z.W. analyzed the data. H.Z. wrote the manuscript. H.Z., J.Z., M.A. and X.L. revised the paper. All authors have read and agreed to the published version of the manuscript.

Funding: The projects supporting this research are "National Key Research and Development Program of China" (NO.2018YFD0501605) and "Livestock and Poultry Genetic Improvement and Healthy Breeding Technology Team of Hubei Agricultural Science and Technology Innovation Center" (NO. 2019-620-000-001-30).

Institutional Review Board Statement: The experimental design of the feeding and digestibility trials was approved by the Laboratory Animal Use and Care Committee in Hubei Science and Technology Agency. This experiment is in line with national regulations regarding animal welfare ethics.

Informed Consent Statement: Not applicable.

Data Availability Statement: The datasets used and/or analyzed during the current study are available from the corresponding author.

Conflicts of Interest: The authors declare that the research was conducted in the absence of any commercial or financial relationships that could be construed as a potential conflict of interest.

\section{Appendix A}

The accession numbers of data of 16S rRNA V3-V4 genes sequencing in NCBI are SRR15970499, SRR15970500, SRR15970501, SRR15970502, SRR15970503 and SRR15970504.

Table A1. Sample tags distribution summary.

\begin{tabular}{|c|c|c|c|c|c|c|c|c|c|}
\hline SampleID & Clean_Tags & Valid Tags & $\begin{array}{c}\text { Valid } \\
\text { Percent }\end{array}$ & $\begin{array}{c}\text { Valid } \\
\text { minlength }\end{array}$ & $\begin{array}{c}\text { Valid } \\
\text { meanLength }\end{array}$ & $\begin{array}{c}\text { Valid } \\
\text { maxLength }\end{array}$ & $\begin{array}{c}\text { Subsample } \\
\text { Depth }\end{array}$ & $\begin{array}{l}\text { OTU } \\
\text { Counts }\end{array}$ & $\begin{array}{l}\text { Total } \\
\text { OTUs }\end{array}$ \\
\hline Rumen0.1 & 61,793 & 48,878 & $79.10 \%$ & 229 & 413.77 & 441 & 26,622 & 3500 & 23,139 \\
\hline Rumen0.2 & 61,657 & 50,779 & $82.36 \%$ & 259 & 413.72 & 441 & 26,622 & 3649 & 23,139 \\
\hline Rumen0.3 & 58,559 & 49,370 & $84.31 \%$ & 229 & 413.82 & 442 & 26,622 & 3456 & 23,139 \\
\hline Rumen0.4 & 60,024 & 49,550 & $82.55 \%$ & 260 & 414.41 & 441 & 26,622 & 3528 & 23,139 \\
\hline Rumen 0.5 & 60,124 & 50,132 & $83.38 \%$ & 230 & 413.50 & 441 & 26,622 & 3483 & 23,139 \\
\hline Rumen0.6 & 58,120 & 48,364 & $83.21 \%$ & 256 & 412.87 & 440 & 26,622 & 3438 & 23,139 \\
\hline
\end{tabular}

\section{References}

1. Rinaldi, R.; Jastrzebski, R.; Clough, M.T.; Ralph, J.; Kennema, M.; Bruijnincx, P.C.A.; Weckhuysen, B.M. Paving the Way for Lignin Valorisation: Recent Advances in Bioengineering, Biorefining and Catalysis. Angew. Chemie Int. Ed. 2016, 55, 8164-8215. [CrossRef]

2. Zakzeski, J.; Bruijnincx, P.C.A.; Jongerius, A.L.; Weckhuysen, B.M. The catalytic valorization of lignin for the production of renewable chemicals. Chem. Rev. 2010, 110, 3552-3599. [CrossRef]

3. Xu, Q.; Zhong, H.; Zhou, J.; Wu, Y.; Ma, Z.; Yang, L.; Wang, Z.; Ling, C.; Li, X. Lignin degradation by water buffalo. Trop. Anim. Health Prod. 2021, 53, 1-8. [CrossRef]

4. Tucker, C.B.; Weary, D.M.; Fraser, D. Effects of three types of free-stall surfaces on preferences and stall usage by dairy cows. J. Dairy Sci. 2003, 86, 521-529. [CrossRef]

5. Belyea, R.L.; Foster, M.B.; Zinn, G.M. Effect of Delignification on In Vitro Digestion of Alfalfa Cellulose. J. Dairy Sci. 1983, 66, 1277-1281. [CrossRef]

6. Atuhaire, A.M.; Kabi, F.; Okello, S.; Mugerwa, S.; Ebong, C. Optimizing bio-physical conditions and pre-treatment options for breaking lignin barrier of maize stover feed using white rot fungi. Anim. Nutr. 2016, 2, 361-369. [CrossRef] [PubMed]

7. Rubin, E.M. Genomics of cellulosic biofuels. Nature 2008, 454, 841-845. [CrossRef] [PubMed]

8. Shao, Y.; Xia, Q.; Dong, L.; Liu, X.; Han, X.; Parker, S.F.; Cheng, Y.; Daemen, L.L.; Ramirez-Cuesta, A.J.; Yang, S.; et al. Selective production of arenes via direct lignin upgrading over a niobium-based catalyst. Nat. Commun. 2017, 8, 1-9. [CrossRef] [PubMed]

9. Boudet, A.M. Lignins and lignification: Selected issues. Plant Physiol. Biochem. 2000, 38, 81-96. [CrossRef]

10. Humphreys, J.M.; Chapple, C. Rewriting the lignin roadmap. Curr. Opin. Plant Biol. 2002, 5, 224-229. [CrossRef]

11. Jung, H.G.; Allen, M.S. Characteristics of plant cell walls affecting intake and digestibility of forages by ruminants. J. Anim. Sci. 1995, 73, 2774-2790. [CrossRef] 
12. Davison, B.H.; Drescher, S.R.; Tuskan, G.A.; Davis, M.F.; Nghiem, N.P. Variation of S/G ratio and lignin content in a Populus family influences the release of xylose by dilute acid hydrolysis. Appl. Biochem. Biotechnol. 2006, 130, 427-435. [CrossRef]

13. Jung, H.G.; Deetz, D.A. Cell wall lignification and degradability. Forage Cell Wall Struct. Dig. 2015, 315-346. [CrossRef]

14. Jung, H.J.G.; Ni, W.; Chapple, C.C.S.; Meyer, K. Impact of lignin composition on cell-wall degradability in an Arabidopsis mutant. J. Sci. Food Agric. 1999, 79, 922-928. [CrossRef]

15. Chen, F.; Dixon, R.A. Lignin modification improves fermentable sugar yields for biofuel production. Nat. Biotechnol. 2007, 25, 759-761. [CrossRef] [PubMed]

16. Grabber, J.H.; Ralph, J.; Hatfield, R.D.; Quideau, S. p-Hydroxyphenyl, Guaiacyl, and Syringyl Lignins Have Similar Inhibitory Effects on Wall Degradability. J. Agric. Food Chem. 1997, 45, 2530-2532. [CrossRef]

17. Fontaine, A.S.; Bout, S.; Barrière, Y.; Vermerris, W. Variation in Cell Wall Composition among Forage Maize (Zea mays L.) Inbred Lines and Its Impact on Digestibility: Analysis of Neutral Detergent Fiber Composition by Pyrolysis-Gas Chromatography-Mass Spectrometry. J. Agric. Food Chem. 2003, 51, 8080-8087. [CrossRef] [PubMed]

18. Li, X.; Ximenes, E.; Kim, Y.; Slininger, M.; Meilan, R.; Ladisch, M.; Chapple, C. Lignin monomer composition affects Arabidopsis cell-wall degradability after liquid hot water pretreatment. Biotechnol. Biofuels 2010, 3, 27. [CrossRef] [PubMed]

19. Uden', P.; Robinson, P.H.; Wiseman, J. Use of detergent system terminology and criteria for submission of manuscripts on new, or revised, analytical methods as well as descriptive information on feed analysis and / or variability. Anim. Feed Sci. Technol. 2005, 118, 181-186. [CrossRef]

20. Robinson, P.H.; Fadel, J.G.; Tamminga, S. Evaluation of mathematical models to describe neutral detergent residue in terms of its susceptibility to degradation in the rumen. Anim. Feed Sci. Technol. 1986, 15, 249-271. [CrossRef]

21. By, E.R.; Mcdonald, I. The estimation of protein degradability in the rumen from incubation measurements weighted according to rate of passage. J. Agric. Sci. 1979, 92, 499-503.

22. Ralph, J.; Hatfield, R.D. Pyrolysis-Gc-Ms Characterization of Forage Materials. J. Agric. Food Chem. 1991, 39, 1426-1437. [CrossRef]

23. Camarero, S.; Bocchini, P.; Galletti, G.C.; Martínez, A.T. Pyrolysis-gas chromatography/mass spectrometry analysis of phenolic and etherified units in natural and industrial lignins. Rapid Commun. Mass Spectrom. 1999, 13, 630-636. [CrossRef]

24. Bolger, A.M.; Lohse, M.; Usadel, B. Trimmomatic: A flexible trimmer for Illumina sequence data. Bioinformatics 2014, 30, 2114-2120. [CrossRef] [PubMed]

25. Magoč, T.; Salzberg, S.L. FLASH: Fast length adjustment of short reads to improve genome assemblies. Bioinformatics 2011, 27, 2957-2963. [CrossRef]

26. Caporaso, J.G.; Kuczynski, J.; Stombaugh, J.; Bittinger, K.; Bushman, F.D.; Costello, E.K.; Fierer, N.; Peña, A.G.; Goodrich, J.K.; Gordon, J.I.; et al. correspondence QIIME allows analysis of high-throughput community sequencing data Intensity normalization improves color calling in SOLiD sequencing. Nat. Publ. Gr. 2010, 7, 335-336. [CrossRef]

27. Edgar, R.C.; Haas, B.J.; Clemente, J.C.; Quince, C.; Knight, R. UCHIME improves sensitivity and speed of chimera detection. Bioinformatics 2011, 27, 2194-2200. [CrossRef] [PubMed]

28. Leplé, J.C.; Dauwe, R.; Morreel, K.; Storme, V.; Lapierre, C.; Pollet, B.; Naumann, A.; Kang, K.Y.; Kim, H.; Ruel, K.; et al. Downregulation of cinnamoyl-coenzyme a reductase in poplar: Multiple-level phenotyping reveals effects on cell wall polymer metabolism and structure. Plant Cell 2007, 19, 3669-3691. [CrossRef]

29. Marita, J.M.; Vermerris, W.; Ralph, J.; Hatfield, R.D. Variations in the cell wall composition of maize brown midrib mutants. J. Agric. Food Chem. 2003, 51, 1313-1321. [CrossRef]

30. Grabber, J.H.; Mertens, D.R.; Kim, H.; Funk, C.; Lu, F.; Ralph, J. Cell wall fermentation kinetics are impacted more by lignin content and ferulate cross-linking than by lignin composition. J. Sci. Food Agric. 2009, 89, 122-129. [CrossRef]

31. Grabber, J.H.; Hatfield, R.D.; Ralph, J. Diferulate cross-links impede the enzymatic degradation of non-lignified maize walls. J. Sci. Food Agric. 1998, 77, 193-200. [CrossRef]

32. Grabber, J.H.; Ralph, J.; Hatfield, R.D. Ferulate Cross-Links Limit the Enzymatic Degradation of Synthetically Lignified Primary Walls of Maize. J. Agric. Food Chem. 1998, 46, 2609-2614. [CrossRef]

33. Grabber, J.H.; Lu, F. Formation of syringyl-rich lignins in maize as influenced by feruloylated xylans and p-coumaroylated monolignols. Planta 2007, 226, 741-751. [CrossRef]

34. Li, F.; Ren, S.; Zhang, W.; Xu, Z.; Xie, G.; Chen, Y.; Tu, Y.; Li, Q.; Zhou, S.; Li, Y.; et al. Arabinose substitution degree in xylan positively affects lignocellulose enzymatic digestibility after various $\mathrm{NaOH} / \mathrm{H} 2 \mathrm{SO} 4$ pretreatments in Miscanthus. Bioresour. Technol. 2013, 130, 629-637. [CrossRef]

35. Wu, Z.; Zhang, M.; Wang, L.; Tu, Y.; Zhang, J.; Xie, G.; Zou, W.; Li, F.; Guo, K.; Li, Q.; et al. Biomass digestibility is predominantly affected by three factors of wall polymer features distinctive in wheat accessions and rice mutants. Biotechnol. Biofuels 2013, 6, 183. [CrossRef] [PubMed]

36. Zhang, W.; Yi, Z.; Huang, J.; Li, F.; Hao, B.; Li, M.; Hong, S.; Lv, Y.; Sun, W.; Ragauskas, A.; et al. Three lignocellulose features that distinctively affect biomass enzymatic digestibility under $\mathrm{NaOH}$ and $\mathrm{H} 2 \mathrm{SO} 4$ pretreatments in Miscanthus. Bioresour. Technol. 2013, 130, 30-37. [CrossRef]

37. Wanapat, M.; Rowlinson, P. Nutrition and feeding of swamp buffalo: Feed resources and rumen approach. Ital. J. Anim. Sci. 2007, 6, 67-73. [CrossRef]

38. Wanapat, M. Rumen manipulation to increase the efficient use of local feed resources and productivity of ruminants in the tropics. Asian-Australasian J. Anim. Sci. 2000, 13, 59-67. 
39. Wang, Z.; Wu, W.; Cui, L.; Li, X.; Kulyar, M.F.E.A.; Xiong, H.; Zhou, N.; Yin, H.; Li, J.; Li, X. Isolation, characterization, and interaction of lignin-degrading bacteria from rumen of buffalo (Bubalus bubalis). J. Basic Microbiol. 2021, 61, 757-768. [CrossRef]

40. Bandounas, L.; Wierckx, N.J.P.; de Winde, J.H.; Ruijssenaars, H.J. Isolation and characterization of novel bacterial strains exhibiting ligninolytic potential. BMC Biotechnol. 2011, 11, 94. [CrossRef]

41. Brown, M.E.; Chang, M.C.Y. Exploring bacterial lignin degradation. Curr. Opin. Chem. Biol. 2014, 19, 1-7. [CrossRef]

42. Masai, E.; Katayama, Y.; Fukuda, M. Genetic and biochemical investigations on bacterial catabolic pathways for lignin-derived aromatic compounds. Biosci. Biotechnol. Biochem. 2007, 71, 1-15. [CrossRef] [PubMed] 